\title{
Studi Kualitatif Fenomenologi Pengalaman Hidup Pasien Pasca Kolostomi di Wilayah Jawa Barat
}

\author{
${ }^{1}$ La Rangki, ${ }^{2}$ Kusman Ibrahim, ${ }^{2}$ Aan Nur' aini \\ ${ }^{1}$ Fakultas Kedokteran Universitas Halu Oleo \\ ${ }^{2}$ Fakultas Keperawatan Universitas Padjadjaran Bandung \\ Email: rangki1979@gmail.com
}

\begin{abstract}
Patient with colostomy followed colorectal has been cancer increasing significantly in Indonesia. Colostomy caused not only physical problems but also psychological and social problems. Health care profesional, especially nurses need to provided hollistic care services to the patients after colostomy. Study with Qualitative method to describe the live experience of the colostomy patient was important. This study was a phenomenological qualitative approach . Data obtained with in-depth interviews to 8 informants consisting of 5 men and 3 women, aged between 30-73 years. The length of time living with a colostomy between 4 months to 6 years. Data were analyzed by using Colaizzi method. Themes emerged from this study: ;sources of support;live with a colostomy; live adaptation; the burdens living with a colostomy. Living with a colostomy faced problems including the limitation to fulfill their needs, psychosocial changes, spiritual distress, and economic problems. Based on those problems, nurses can give support and attention for post colostomy patients.
\end{abstract}

Keywords : Lived Experiences, Colostomy, Bandung

\section{PENDAHULUAN}

\section{World Health Organization}

(WHO) (2008) menyatakan bahwa kanker kolon dan rektal merupakan penyebab tersering ketiga kanker yang terjadi pada pria dan penyebab tersering kedua kanker yang terjadi pada wanita di seluruh dunia pada tahun 2008.

Penelitian ini dilandasi pada masih kurangnya informasi terkait dengan kondisi hidup pasien pasca kolostomi, yang berdampak pada tidak optimalnya perawatan pasien psca kolostomi secara komprehensif dengan pendekatan biologis, psikologis, sosial, spiritual dan kultural. Sekalipun di luar negeri telah banyak dilakukan penelitian serupa, namun demikian dengan perbedaan latar belakang budaya, status sosial dan ekonomi, serta tingkat pendidikan masyarakat Indonesia yang masih bervariasi, kemungkinan besar akan muncul pengalaman hidup yang berbeda pula dengan pasien kolostomi di luar negeri.

Pelayanan asuhan keperawatan yang tidak holistik ini, akan berdampak pada kurangnya dukungan psikologis klien dalam menjalani kehidupan dengan stoma, dan akan menurunkan kemampuan klien dalam menghadapi perubahanperubahan yang terjadi akibat stoma, sehingga akan berpengaruh pada penurunan kualitas hidup pasien stoma (Brown \& Randle, 2005).

Prevalensi kanker kolon dan rektal yang makin meningkat di 
seluruh dunia menjadikannya sebagai salah satu masalah kesehatan global yang serius. Setiap tahun, diperkirakan sebanyak 550.000 penduduk dunia meninggal akibat kanker kolon dan rektal (Brown \& Bois, 2005).

Menurut Murna (2004) kanker kolon dan rektal merupakan penyakit yang menjadi penyebab kematian kedua tertinggi di antara semua jenis keganasan di negara berkembang. Di Indonesia, kanker kolon dan rektal merupakan jenis keganasan saluran pencernaan terbanyak kedua setelah keganasan hepatoseluler dan menempati urutan keenam dari penyakit keganasan (Pusponegoro, 2004). Sedangkan Indonesian Cancer mencatat 3.572 kasus baru kanker kolon dan rektal ditemukan di Indonesia pada tahun 2002 (Abdullah, 2004).

Informasi yang baru (new insight), dari pengalaman hidup pasien dengan stoma tersebut, akan menjadi dasar dalam pemberian asuhan keperawatan yang lebih komprehensif bagi pasien stoma, Penelitian ini bertujuan untuk mengungkap secara mendalam tentang pengalaman hidup pasien dengan stoma pasca kolostomi.

\section{METODE PENELITIAN}

Penelitian ini menggunakan jenis penelitian kualitatif pendekatan fenomenologi. Penelitian ini dilaksanakan pada bulan april tahun 2014, dengan terhadap 8 informan yang menggunakan teknik purposive sampling. Dengan kriteria inklusi dalam penentuan informan yakni:

a. Individu dengan diagnosa medis mengalami kanker kolon dan rektal yang telah menjalani tindakan kolostomi dalam waktu minimal empat bulan.

b. Kondisi umum stabil.

c. Mampu berkomunikasi dengan baik dan kooperatif

d. Pasien bersedia menjadi informan pada penelitian ini

Kriteria eksklusi dalam penentuan informan yaitu: individu yang termasuk kriteria inklusi namun dengan kondisi yang tidak memungkinkan dalam proses pengumpulan data dimana pasien mengalami penurunan kondisi kesehatan.

Sebelum peneliti melakukan pengumpulan data, terlebih dahulu melakukan pengurusan ijin penelitian dari Fakultas Ilmu Keperawatan Universitas Padjadjaran, yang ditujukan kepada RSUP dr. Hasan Sadikin Bandung, selanjutnya mendapatkan persetujuan etik dari Tim Etik Penelitian serta meminta persetujuan dari informan untuk menjadi responden penelitian.

Pengumpulan data dilakukan di ruang rawat inap RSUP Dr. Hasan Sadikin Bandung, dengan wawancara mendalam (in-depth interview), dengan pertanyaan secara terbuka dengan pertanyaan pembuka yakni "Bagaimana Pengalaman Hidup Responden Dalam Menjalani Hidup 
Dengan Kolostomi”, dari pertanyaan tersebut, berkembang menjadi sebuah wawancara yang lebih luas dan mendalam, serta dengan alat perekam suara menggunakan voice recorder, yang dilakukan oleh peneliti sendiri, dengan alokasi waktu berkisar 60 menit sampai dengan 75 menit untuk tiap informan dengan syarat saturasi data yang diperoleh telah jenuh. Selanjutnya peneliti melakukan analisis data menggunakan metode Colaizzi. Menurut Creswell (2007) bahwa dari ketiga metode yang tersering digunakan dalam analisis studi fenomenologi, hanya metode Colaizzi yang melibatkan klarifikasi balik kepada informan terkait hasil analisis. Tahap-tahap analisis data menurut Colaizzi sebagaimana dikemukakan oleh Wojnar dan Swanson (2007) adalah sebagai berikut:

1) Membaca keseluruhan deskripsi informan tentang fenomena yang sedang diteliti.

2) Memisahkan pernyataanpernyataan signifikan.

3) Menformulasikan makna dari setiap pernyataan signifikan

4) Mengkategorisasikan setiap unit makna menjadi satu tema/cluster makna.

5) Mengintegrasikan setiap tema menjadi deskripsi yang lengkap.

6) Memvalidasi hasil analisis kepada informan

7) Menyempurnakan hasil analisis dengan data yang diperoleh selama proses validasi.
Menurut Lincoln dan Guba (1985) mengemukakan bahwa Rigor (trustworthiness) penelitian dikatakan kredibel ketika menyajikan deskripsi atau data dengan kriteria tertentu ketika peneliti atau pembaca dihadapkan dengan pengalaman tersebut akan dengan mudah bisa dikenali. Untuk mendapatkan keabsahan data, diperlukan teknik pemeriksaan didasarkan atas sejumlah kriteria tertentu, yaitu credibility, trasferability, dependability, serta confirmability.

Terkait dengan kredibilitas data pada penelitian ini, peneliti menggunakan cara yakni hasil analisis data yang telah dilakukan, divalidasi kembali oleh informan serta disetujui oleh informan terkait kebenaran data dan analisis data tersebut, selanjutnya peneliti juga memberikan data dan analisis data hasil rekaman kepada ahli dibidang penelitian fenomenologi serta pembimbing yang lebih mengerti akan topik penelitian ini.

\section{HASIL PENELITIAN}

Pada penelitian ini diperoleh empat tema yang merupakan kompilasi dari seluruh pengalaman informan yang hidup dengan stoma yakni:

\section{Sumber-Sumber Dukungan Bagi Informan.}

Upaya menjalani hidup dengan stoma, adaptasi terhadap perubahan 
yang terjadi, dan penyulit dalam menjalani hidup dengan kolostomi.

Adapun penjabaran setiap tema adalah sebagi berikut: dari hasil penelitian ini yaitu adanya sumbersumber dukungan bagi informan. Pada penelitian ini setiap informan banyak mendapatkan dukungan dari berbagai pihak, dukungan tersebut sangat bermanfaat bagi kelangsungan hidup informan setelah menjalani hidup dengan kolostomi. Pada tema ini teridentifikasi tiga subtema yaitu dukungan keluarga, dukungan kelompok, dan dukungan dari dokter dan perawat.

Pada penelitian ini semua informan mendapatkan dukungan dari keluarga, mulai dari sejak didiagnosis kanker kolon dan rektal hingga setelah operasi kolostomi. Sebagaimana ungkapan informan berikut ini: “....sejak dari rumah sakit ketika dirawat saya selalu ditemani, termasuk setelah operasi, saya dilatih duduk, terus berdiri kemudian berjalan dan selalu dimotivasi untuk tetap kuat..."(I.2) Selain mendapat dukungan dari keluarga, informan juga mendapat dukungan dari temanteman kerja. Sebagaimana pernyataan informan berikut: “.....saya ikut dalam perhimpunan pasien stoma Jabar, untuk berbagi informasi” (I.1) Informan juga mendapatkan dukungan dari keluarga dan teman kerja. Informan juga mendapat dukungan dari dokter dan perawat. Berikut ungkapannya: “.....saya mendapatkan dukungan dari dokter dan perawat dan mengajarkan cara ganti kantong...." (I.2).

\section{Adaptasi Hidup Dengan Stoma}

Secara umum upaya yang dilakukan oleh informan terdiri dari penguatan secara spiritual dan penguatan dengan motivasi diri sendiri. Informan dalam penelitian ini melakukan upaya dengan meningkatkan nilai-nilai spiritual sebagai upaya untuk menerima kondisinya, sebagai bagian dari cobaan yang diberikan oleh Tuhan. Berikut ungkapan informan: ".....saya ikut dalam pengajian lingkungan, ibadah saya makin baik malah sekarang ini, soalnya saya takut mati karena persiapan saya belum banyak, jadi dengan kondisi ini saya tetap menerima dan saya jadi kuat lagi, soalnya kalo hanya dirumah saya banyak stress, jadi saya banyak bergaul, jadi kuat lagi...." (I.4) Informan dalam penelitian ini melakukan upaya dengan meningkatkan penguatan pada jiwanya sebagai upaya untuk menerima kondisinya, sebagai bagian dari hidup yang harus dijalani. Berikut ungkapan informan: “.....awalnya saya bingung harus hidup dengan kondisi begini, trus saya ingin cepat sembuh dan lihat anak dan suami juga,

kasian kalo saya bikin susah mereka, jadi saya harus kuat dalam menjalani hidup ini, trus saya selalu baca-baca informasi di internet, banyak saya dapat informasi untuk rawat luka dan gani kantong...." (I.8) Pada penelitian 
ini ditemukan ungkapan beberapa informan yang mengalami perubahan setelah menjalani pembedahan kolostomi serta upaya adaptasi yang dijalani dalam mengatasi setiap hal yang terjadi. Pada penelitian ini peneliti menggolongkan kemampuan adaptasi bagi informan berdasarkan kelompok masalah yang timbul yakni adaptasi fisik dan psikososial. Pada penelitian ini semua informan mengalami kesulitan untuk menggerakkan badan akibat kelemahan yang dirasakan setelah pembedahan. Keluhan lemah dirasakan hingga 20 hari bahkan hingga dua bulan. Sebagaimana ungkapan informan berikut ini: ".....saya merasakan lemah yang parah setelah operasi sampai 20 hari setelah operasi baru bisa saya bangun, mungkin karena usia saya sudah tua, makanya saya baring terus...."(I.1) Pada penelitian ini juga diperoleh informasi bahwa informan melakukan adaptasi dengan latihan fisik yang dibantu oleh keluarga dan orang terdekat. Berikut ungkapan informan: “......setelah 20 hari baru saya mulai latihan duduk di tempat tidur, trus saya dilatih untuk berdiri disamping tempat tidur, hingga akhirnya saya latihan jalan dikamar dan diluar kamar, latihan selalu dibantu istri dan anak..." (I.1) Pada penelitian ini juga ditemukan ungkapan informan mengenai adaptasi terhadap perubahan yang terjadi secara psikologis, terutama terkait dengan perubahan konsep diri citra tubuh akibat operasi kolostomi. Informan merasakan sesuatu yang berbeda dengan sebelum operasi, dimana saat setelah operasi informan merasa tidak nyaman dengan kantong kolostomi yang menempel pada dinding perutnya. Berikut ungkapan informan: ".....setelah operasi saya merasa risih dan malu bertemu dengan orang lain, saya butuh waktu tiga bulan untuk bisa menerima kondisi saya, berat rasanya mendapat cobaan seperti ini pak..." (I.2) Pada penelitian ini juga ditemukan adaptasi informan terhadap proses interaksi sosial dengan lingkungan dan masyarakat disekitarnya. Sebagian besar informan membutuhkan waktu yang bervariasi dan dukungan keluarga sangat besar terhadap kemampuan tersebut. Berikut ungkapan informan: “.....setelah operasi selama dua bulan tidak pernah keluar rumah, soalnya saya malu sekali sama orang lain, saya pikir tidak mungkin begini terus, makanya saya mulai kedatangan tamu dari tetangga trus teman dekat, hingga akhirnya saya mulai bergaul dengan orang lain, saya selalu dikuatkan oleh mereka, agar saya jangan menyendiri dan selalu berbagi cerita kata perawat dirumah sakit juga begitu, makanya saya mulai masuk kerja lagi setelah tiga bulan pasca operasi, meskipun kerjaan saya tidak seberat dulu, sekarang saya hanya duduk saja sebagai satpam....”(I.2) 


\section{Penyulit Hidup Dengan Kolostomi}

Pada penelitian ini juga ditemukan terdapat beberapa ungkapan informan yang mengalami kondisi yang dapat menambah kesulitan dalam hidup dengan kolostomi, yaitu kesulitan ekonomi, kurangnya informasi dari petugas kesehatan, komplikasi pascakolostomi, pengalaman terhadap rasa nyeri, dan akses pelayanan kesehatan yang jauh. Perubahan pada aspek ekonomi juga dialami oleh semua informan. Sebagian besar biaya operasi dijamin oleh asuransi, namun dalam perjalanannya tetap menggunakan biaya pribadi untuk biaya belanja kantong dan biaya hidup lainnya. Berikut ungkapan informan: “....saya harus terapi kemo kelas tinggi tapi tidak masuk jaminan,saya nunggu informasi dari dokter dulu kata perawat. sulit juga kalau tidak ada pekerjaan tetap.." (I.3) "....saya jual motor dan emas untuk biaya obat dan beli kantong..." (I.7) “...saya sulit kerja saat ini, kebutuhan rumah tangga hanya dari istri..." (I.3) Selain penyulit faktor finansial bagi informan, juga kurangnya informasi dari pemberi pelayanan kesehatan terhadap informan. Tenaga kesehatan yang berperan adalah dokter dan perawat. Berikut ungkapan informan: “.....saya tidak tahu, mau dioperasi apa,saya sadar rupanya begini kondisi saya..." (I.6) “.....seharusnya dokter itu bilang dulu kesaya, tapi hanya bilang sama keluarga, jadi saya bingung dengan kondisi ini...." (I.6) “.....dokter digarut jarang bicara, beda dengan dokter di hasan sadikin yang suka menjelaskan..." (I.7) Terdapat informan yang mengalami keluarnya usus dari lubang kolostomi pasca menjalani bedah kolostomi, sebagaimana ungkapan informan berikut: “....setelah operasi usus saya keluar dari lobang dinding perut,mungkin terlalu banyak jalan dan naik motor sama istri..."(I.3) Pengalaman terjadinya iritasi pada kulit sekitar stoma juga dialami oleh beberapa informan. Hal ini terjadi akibat dari rembesan produksi feses yang mengenai area kulit sekitar stoma. berikut pernyataan informan: “....kulit saya iritasi akibat isi kantong merembes dikulit sekitar kantong stoma...." (I.1) “....kalo ganti kantong saya ada lecet dikulit...." (I.6) Pada penelitian ini informan mengalami efek samping kemoterapi maupun radioterapi. Informan mengalami mencret, mual, muntah, bahkan rambut rontok. Berikut ungkapan mereka: "saya jalani kemoterapi rasanya berat pada kemo yang kelima saja, kalo siklus awal saya tidak merasakan apa-apa, trus pada kelima saya merasakan mual, muntah dan rambut rontok, biasa bangun pagi bantal banyak rambutnya, tapi tidak sampai botak" (I.3) Pengalaman rasa nyaman nyeri juga dialami sebagian besar informan. Rasa nyeri ini muncul akibat adanya luka sayatan operasi kolostomi. Berikut ungkapan 
informan: “.....empat hari setelah bius saya hilang, maka saya merasakan sakit sekali, saya malah mengigau karena terlalu sakitnya, terus saya juga tidak bisa tidur, gerakan badan juga sakit, akhirnya saya dikasih obat supaya rasa nyerinya hilang...." (I.1) Pengalaman yang juga dialami oleh informan dalam penelitian ini adalah hambatan dalam akses pelayanan kesehatan bagi informan yang telah menjalani pembedahan kolostomi. “....usus saya pernah keluar, trus saya harus ke rumah sakit, puskesmas tidak ada alat katanya untuk tindakan, aduh susah pak, harus ke rumah sakit dulu...." (I.3) Semua informan juga diharuskan menjalani kemoterapi dan radioterapi di Rumah Sakit Hasan Sadikin. Setiap tindakan kemoterapi maupun sinar tidak dapat dilakukan di Rumah Sakit Daerah, dengan alasan belum ada fasilitas untuk terapi tersebut. Kondisi tersebut banyak dikeluhkan oleh informan: "....habis saya operasi di garut, dirujuk ke bandung untuk kemo, jauh sekali pak,saya masih lemah harus ke bandung..." (I.5) “....tiga bulan setelah operasi saya dirujuk di hasan sadikin untuk kemo, saya harus sewa kamar kos tiap bulan enam ratus ribu...." (I.7)

\section{PEMBAHASAN}

Penelitian ini menunjukkan hasil bahwa Selanjutnya juga timbul rasa malu dan minder pada pasangan akibat adanya kantong pada dinding perut informanseperti yang dialami oleh informan dua. Munculnya rasa risih atau minder dengan pasangan berdampak pada kesulitan untuk pemenuhan kebutuhan seksual, hal ini akan berakibat pada munculnya rasa tidak nyaman terhadap pasangan masingmasing. Hal ini membutuhkan dukungan informasi yang cukup bagi setiap pasangan untuk dapat menyelesaikan setiap masalah yang muncul dari pasangan berkaitan dengan seksual. Sehingga akan diperoleh kehidupan seksual yang sehat bagi pasien dengan stoma. Kecemasan tentang kemampuan untuk melakukan hubungan seksual dan perasaan khawatir terhadap peralatan stoma selama hubungan seksual, dapat menimbulkan penolakan keintiman dengan pasangannya (Black, 2004). Pada penelitian ini, dukungan sosial juga dirasakan oleh informan setelah menjalani operasi kolostomi. Dukungan didapatkan dari keluarga, teman kerja, dan tetangga di tempat tinggal. Dukungan dari keluarga ini sangat penting, mengingat keluarga dituntut untuk memberikan dukungan yang lebih besar dibandingkan dengan dukungan dari orang lain. Dukungan keluarga meliputi dukungan terhadap sikap, tindakan, dan penerimaan keluarga terhadap informan setelah operasi kolostomi. Menurut The National Council for Palliative Care (NCPC) (Joshland dkk., 2011) mengemukakan bahwa keluarga merupakan orang yang selalu dilibatkan dalam setiap tindakan pemberian pelayanan oleh tenaga kesehatan. Keluarga selalu mendampingi informan dalam setiap kondisi dan perawatan yang dimulai dari prediagnosis, saat proses penegakkan diagnosis dan pengobatan, selama sakit atau bahkan sampai kematian. Pada penelitian ini ditemukan informasi mengenai bagaimana individu melakukan strategi koping setelah hidup dengan 
stoma. Strategi koping yang digunakan lebih banyak mengarah pada mencari teman sesama penderita stoma, ikut dalam perhimpunan stoma, termasuk selalu mencari berita-berita dari internet dengan tujuan untuk berbagi pengalaman dan informasi sehingga dapat mempercepat informan dalam menerima kondisinya. Informan mengatakan bahwa banyak keuntungan bila selalu bergaul dengan sesama penderita, sebab informan saling berbagi informasi maupun perasaan masingmasing, sehingga mereka memiliki kekuatan yang lahir dari diri mereka sendiri. Dengan demikian, informan memiliki kemampuan untuk hidup dengan stoma. Menurut Vujnovich (2008), mekanisme koping dikategorikan menjadi dua yaitu koping aktif (active coping) dan koping yang menghindar (aviodant coping). Koping aktif akan dapat memecahkan suatu masalah dengan berbagai perencanaan dan tindakan seperti pencarian informasi dan dukungan dan atau pemilihan jalan keluar terhadap suatu kejadian sebagai jalan untuk adaptasi. Sedangkan koping menghindar merupakan karekteristik terjadinya kegagalan dalam menghadapi kejadian stres dengan melakukan berbagai kegiatan atau aktivitas yang buruk, seperti pemakaian obat, akohol sehingga sangat buruk dalam hal melakukan adaptasi terhadap stres. Pada penelitian ini ditemukan sebagian besar informan mengalami perubahan pada fisik maupun psikososial yang berdampak pada kondisi informan secara umum. Beberapa informan melakukan upaya dalam mengatasi dan menerima kondisinya dengan berbagai cara dan pendekatan. Secara umum, semua informan membutuhkan dukungan yang optimal baik dari keluarga dan orang terdekat dalam upaya untuk menjalani hidup dengan kolostomi. Tindakan pembedahan yang dilakukan pada pembentukan stoma merupakan masalah yang besar dalam hidup pasien sehingga membuntuhkan penyesuaian psikologis yang cukup. Pasien mengalami masalah psikologis sampai tingkat tertentu baik pra atau pascaoperasi (Black, 2004). Pada periode pascaoperasi, mekanisme koping menjadi kelebihan beban akibat hilangnya kepercayaan, kemandirian dan sering pasien mungkin berupaya untuk mengatasi masalah yang berkaitan dengan harkat dan martabat sebagai pasien dengan stoma (Black, 2004). Selanjutnya Offman (1995) dalam Black (2004) menunjukkan bahwa efek psikologis operasi stoma lebih besar daripada efek fisik atau pun farmakologis. Perubahan pada gambaran tubuh dan berkabung atas kehilangan bagian tubuh akibat tindakan operasi, dapat dipandang sebagai masalah pada fisik ataupun seksual yang mengganggu keutuhan tubuh. Pertimbangan utama dalam hal adaptasi setelah operasi stoma tampaknya akan membutuhkan waktu yang lama dalam proses berduka (Black, 2004). Masalah lain yang dikemukakan juga oleh informan yaitu adanya perubahan status ekonomi yang juga dirasakan oleh informan setelah dirinya hidup dengan kolostomi. Pada informan walaupun biaya operasi sebagian besar dibiayai oleh jamkesmas, namun bagi informan lima dengan biaya sendiri dengan menjual motor yang dimilikinya. Setelah operasi pun tetap butuh biaya perawatan dan kantong kolostomi, sehingga informan pun tetap membutuhkan biaya yang tidak sedikit, terlebih lagi untuk jangka panjang. Hal 
ini tetap menjadi beban bagi semua informan baik bagi pensiunan maupun karyawan swasta terlebih lagi bagi informan yang tidak bekerja. Setiap informan mengalami perubahan pada kondisi ekonomi atau keuangan, terlebih lagi bagi informan yang tidak memiliki pekerjaan tetap, sehingga berdampak pada keuangan rumah tangga termasuk dalam hal upaya pemenuhan kebutuhan keluarga. Kondisi perekonomian yang kurang ini akan berdampak pada terbatasnya pilihan jenis kantong dan terapi bagi pasien. Hal ini juga akan memperberat kondisi penyakit dari informan tersebut. Pasien dengan kolostomi cenderung menghadapi berbagai masalah yang kompleks, seperti perubahan pada fisik, mental, emosional, sosial, seksual serta ekonomi (Panusur \& Rika, 2007).

\section{SIMPULAN}

Berdasarkan hasil penelitian ini dapat disimpulkan bahwa pengalaman yang dialami oleh informan dengan kolostomi berupa keterbatasan dalam melakukan aktivitas sehari-hari, perubahan psikososial informan, perubahan dalam perilaku ibadah atau distres spiritual, berbagai sumber dukungan bagi informan, upaya menjalani hidup dengan stoma, serta penyulit hidup dengan kolostomi. Hasil penelitian ini menemukan new insight berupa individu yang hidup dengan kolostomi mengalami distres spiritual. Temuan lain juga terkait dengan kurangnya informasi yang dialami oleh beberapa informan dan kesulitan terhadap akses pelayanan kesehatan dalam menjalani kemoterapi dan radioterapi terutama informan yang berada di luar daerah Bandung.

\section{SARAN}

Hasil penelitian ini dapat dijadikan acuan bagi perawat dalam melakukan pengkajian kebutuhan asuhan keperawatan pada pasien pascakolostomi. Selanjutnya hasil penelitian ini juga dapat dijadikan sebagai dasar rujukan bagi penelitian selanjutnya yang berkaitan dengan pengembangan model intervensi pada pasien dengan kolostomi.

\section{DAFTAR PUSTAKA}

Abdullah, M. 2004. Clinical Characteristics of Colorectal Cancer in Indonesia. Dalam: the Multidisciplinary Cancer Management of Solid Tumors. Proceeding temu ilmiah, Jakarta, April. 5-7: 33-35.

Black, P. 2004. Psychological, Sexual and Cultural Issues for Patients With a Stoma. British Journal of Nursing. 13 (12) : 692-694,696-697.

Brown, H., \& Randle, J. 2005. Living With a Stoma: a Review of The Literature. Article first published online: 1365-2702.

Creswell, J.W. 2007. Qualitative Inquiry and Research Design Choosing Among Five Traditions. SAGE Publications, Inc. Mississipi.

Joshland,.,Brennan,F.,Anastasiou,A \& Brown, A.M. 2011. Developing and Sustaining a Renal Supportive Care Services for People With End Stage Renal Disease. Renal Society of Australia Journal. 8(1) : 12-18. 
Brown, J.R., .\& Du Bois, R.N., 2005. COX-2: a Molecular Target for Colorectal Cancer Prevention. Journal Clinical Oncology. 23(12): 2840-2855.

Lincoln, Y.S., \& Guba, E.G. 1985. Naturalistic Inquiry. Misisipi: SAGE Publications, Inc.

Murna, I.W. 2004. Imaging of Colorectal Cancer. Dalam: the Multidisciplinary Cancer Management of Solid Tumor : Breast, Colorectal and The Sarcomas Today \& Tomorrow. Jakarta.

Panusur \& Rika. 2007. Kemampuan Self Care dan Gambaran Diri Pasien kolostomi di RSUP. H. Adam Malik Medan. Dikutip dari:

Repository.usu.ac.id/bitstream. Diakses tanggal 30 september 2013.
Pusponegoro, A. D. 2004. Epidemiologi Keganasan Saluran Cerna. Proceeding temu ilmiah Dalam: the multidisciplinary cancer management of solid tumors: breast, colorectal and the sarcomas today \& tomorrow. Jakarta

Vujnovich, A. 2008. Pre and PostOperative Assessment of Patients With a Stoma. Nursing Standard; Nursing \& Allied Health Source 50.

Wojnar, D.M., \& Swanson, K. 2007. Phenomenology: An Exploration. Journal Holistic Nursing. 25: 172.

World Health Organization. 2008. Colorectal Cancer Incidence, Mortality and Prevalence Worldwide in 2008. Diperoleh dari: http://globocan.iarc.fr/. Diakses pada 30 Oktober 2012. 